\title{
Perlindungan Hukum Terhadap Independensi Kurator dalam Mengurus dan Membereskan Harta Pailit
}

\author{
Novitasari $^{1}$, Tata Wijayanta ${ }^{2}$ \\ ${ }^{1}$ Fakultas Hukum Universitas Gadjah Mada \\ Bulaksumur, Daerah Istimewa Yogyakarta 55281, Indonesia \\ Telp/Fax: +62 (274) 588688 E-mail : Novitaeffendi06@yahoo.com \\ ${ }^{2}$ Fakultas Hukum Universitas Gadjah Mada \\ Bulaksumur, Daerah Istimewa Yogyakarta 55281, Indonesia \\ Telp/Fax: +62 (274) 588688 E-mail:wijayanta@mail.ugm.ac.id
}

Diterima: 25/05/2016.; Revisi: 23/08/2016; Disetujui: 25/09/2016

\begin{abstract}
This research are aimed at: (1) identifying and investigating the problems of the independency of Curators in performing their duties to settle the insolvent estate to the emergence of a lawsuit from the bankrupt debtor; (2) identifying and investigating the standard in determining the independence of Curator in performing their duties to settle and administer the insolvent estate; and (3) identifying and investigating legal protection for Curator in performing their duties. This research is an empirical normative legal research. Data included primary data and secondary data. The primary data were obtained through interviews with interview guide, while secondary data were obtained through documentation method with documentation tools. The data were analyzed qualitatively. The research results indicated that the lawsuits against the Curators performed by debtors and creditors were basically from few cases experienced by the curators only aimed at preventing the settlement process of insolvent estate, resulting in the increase of bankruptcy costs, especially in terms of the cost of securing assets that must be borne by the curators and the longer time to settle. Moreover, there are no provisions regarding the standards or parameters of the independence of the curators, making it difficult to identify the independence of curators in performing their duties, and Law Number 37 of 2004 on Bankruptcy And Suspension of Debt Payment Obligation did not provide in writing about the legal protection for the profession of Curators in performing their duties. This research concluded that: (1) the independence of the curators is not the main cause of a lawsuit of the debtor and the creditor; (2) the independence of the curator is difficult to be identified; and (3) legal protection for the curators has been regulated in the 1945 Constitution of the Republic of Indonesia and the ethical code of the Indonesian Curator and Administrators Association (AKPI) as one of the Curator organizations. Based on these conclusions it is suggested that: (1) it is necessary to establish
\end{abstract}


provisions concerning sanctions of the emergence of a lawsuit undertaken by the debtor and the creditor against the Curator which is aimed at preventing the process of settlement; (2) it is necessary to establish provisions concerning standards or parameters of the independence of Curator, and (3) it is not necessary to make specific rules concerning the legal protection for the profession of Curator.

Keywords: Independence, Legal Protection, Curator, Insolvent Estate

Abstrak: Penelitian ini bertujuan untuk: (1) mengetahui dan mengkaji permasalahan independensi Kurator dalam melaksanakan tugas membereskan harta pailit terhadap munculnya gugatan dari debitor pailit, (2) mengetahui dan mengkaji tolok ukur menentukan independensi Kurator dalam melaksanakan tugasnya membereskan dan mengurus harta pailit serta, dan (3) perlidungan hukum terhadap Kurator dalam melaksanakan tugasnya. Penelitian ini merupakan penelitian hukum normatif empiris. Data yang digunakan dalam penelitian ini berasal dari data primer dan data sekunder. Data primer diperoleh melalui wawancara dengan alat pedoman wawancara, sedangkan data sekunder diperoleh melalui metode dokumentasi dengan alat studi dokumentasi dan analisis data dilakukan secara kualitatif. Hasil penelitian menunjukkan, bahwa gugatan terhadap Kurator yang dilakukan oleh debitor maupun kreditor pada dasarnya dari beberapa kasus yang dialami Kurator, hanya bertujuan untuk menghambat proses pemberesan harta pailit, akibatnya biaya kepailitan membengkak, terutama dalam hal biaya pengamanan aset yang harus ditanggung Kurator dan waktu untuk membereskan menjadi lebih lama, kemudian tidak ada ketentuan mengenai tolok ukur/parameter independensi Kurator, sehingga sulit mengidentifikasi Kurator independen atau tidak dalam melaksanakan tugasnya, dan Undang Undang Nomor 37 Tahun 2004 tentang Kepailitan dan Penundaan Kewajiban Pembayaran Utang tidak memberikan secara tertulis mengenai perlidungan hukum terhadap profesi Kurator dalam melaksanakan tugasnya. Kesimpulan penelitian adalah: (1) independensi Kurator bukan penyebab utama munculnya gugatan oleh debitor maupun kreditor, (2) independensi Kurator sulit diindentifikasi, dan (3) perlindungan hukum terhadap Kurator telah diatur dalam UUD 1945 dan kode etik AKPI sebagai salah satu organisasi Kurator. Berdasarkan kesimpulan tersebut, maka disarankan: (1) perlu diatur ketentuan mengenai sanksi dari munculnya gugatan yang dilakukan oleh debitor maupun kreditor terhadap Kurator yang bertujuan menghambat proses pemberesan; (2) perlu diatur ketentuan mengenai tolok ukur/parameter independensi Kurator; dan (3) tidak perlu dibuatkan aturan khusus mengenai perlidungan hukum terhadap profesi Kurator.

Kata-kata Kunci: Harta Pailit, Independensi, Kurator, Perlindungan Hukum 


\section{PENDAHULUAN}

Menurut Pasal 1 angka 1 Undang Undang Nomor 37 Tahun 2004 tentang Kepailitan dan Penundaan Kewajiban Pembayaran Utang (Lembaran Negara Republik Indonesia Tahun 2004 Nomor 131, Tambahan Lembaran Negara Republik Indonesia Nomor 4443; untuk selanjutnya disebut UU No. 37/2004) kepailitan diartikan sebagai sita umum atas semua kekayaan debitur pailit yang pengurusan dan pemberesannya dilakukan oleh kurator dibawah pengawasan hakim pengawas. Kurator dalam proses kepailitan memiliki peranan penting. Dalam Pasal 15 ayat (1) UU No. 37/200 disebutkan, bahwa Kurator harus diangkat beserta hakim pengawas yang ditunjuk oleh Hakim Pengadilan untuk mengurus dan membereskan harta pailit.

Kurator, berwenang melaksanakan tugas pengurusan dan/atau pemberesan atas harta pailit, terhitung sejak tanggal putusan pernyataan pailit ditetapkan. Kewenangan tersebut berlaku meskipun terhadap putusan yang diajukan kasasi atau peninjauan kembali. ${ }^{1}$ Tugas Kurator dalam melakukan pemberesan dan pengurusan sebagaimana dimaksud Pasal 16 Undang Undang Kepailitan dan Penundaan Kewajiban Pembayaran Utang dalam praktik sulit sekali dilakukan apabila debitor pailit melakukan perlawanan. Perlawanan yang dimaksud baik perlawanan dari debitor pailit terhadap Kurator untuk masuk ke tempat harta pailit, debitor atau kreditor melakukan gugatan terhadap Kurator dalam melaksanakan tugasnya maupun pelaporan Kurator kepada pihak Kepolisian yang dianggap melakukan tindakan merugikan harta palit milik debitor Pailit, sehingga Kurator sulit untuk melakukan

1 Rahayu Hartini. 2008. Hukum Kepailitan. Malang: UMM Press, hlm. 127. pengurusan dan atau pemberesan harta pailit. Salah satu contoh kasus pada tahun 2014 mengenai sengketa pailit PT Metro Batavia atau dikenal dengan Batavia Air belum berakhir, setelah digugat actio pauliana oleh tim Kurator Batavia Air, Mantan Direktur Utama Batavia YT mengugat balik Kurator karena memasukkan harta pribadinya dalam budel pailit. ${ }^{2}$ Ketika Kurator dalam hal ini digugat oleh debitor maupun kreditor pada waktu pemberesan harta pailit dimungkinkan adanya masalah ketidak independenan dari Kurator dalam melaksanakan tugasnya, terkait siapa yang mengajukan penunjukan Kurator tersebut, artinya gugatan yang diajukan oleh debitor ataupun kreditor diakibatkan oleh ketidakpercayaan debitor terhadap proses pemberesan harta pailit yang dilakukan oleh Kurator yang ditunjuk oleh salah satu pihak. Permasalahan tersebut di atas menandakan bahwa independensi Kurator dalam melaksanakan tugas dan kewenanganya perlu dipertanyakan. Hal ini berkaitan dengan tanggung jawab Kurator selama melaksanakan tugasnya apakah sesuai dengan independen, seperti yang dimaksud dalam ketentuan UU No. 37/2004 dan Kode Etik Profesi Kurator, yang secara jelas menghendaki agar menjunjung tinggi independensi, integritas dan objektifitasnya. Berdasarkan latar belakang masalah penelitian yang diuraikan di atas, dapat dirumuskan isu hukumnya, yaitu: (1) apakah permasalahan independensi Kurator dalam melaksanakan tugas membereskan harta pailit menjadi penyebab munculnya gugatan dari debitor pailit; (2) bagaimana menentukan tolok ukur independensi Kurator menurut UU No. 37/2004?; dan (3) bagaimana perlindungan

2 http://bisniskeuangan.kompas.com/Dirut.Batavia. Air.Gugat.Balik.Tim.Kurator, Diakses pada tanggal 18 Juli 2015 
hukum terhadap Kurator dalam melaksanakan kewenangannya mengurus dan membereskan harta pailit?

\section{METODE}

Penelitian hukum ini merupakan penelitian hukum normatif empiris. Penelitian hukum normatif empiris merupakan penelitian yang menggabungkan antara penelitian hukum normatif dan penelitian hukum empiris yang menggunakan data sekunder dan data primer melalui jenis penelitian kepustakaan dan lapangan. Fokus penelitian hukum normatif empiris selalu diarahkan pada dua hal, yakni pertama penerapan ketentuan hukum normatif dan kedua hasil yang dicapai. ${ }^{3}$

Analisis data dalam penelitian ini, yakni seluruh data yang diperoleh dari kepustakaan, responden dan narasumber kemudian dianalisis secara kualitatif. Dalam penelitian ini menganalisis data-data kepustakaan dan keterangan-keterangan hasil wawancara dengan responden dan narasumber mengenai perlindungan hukum terhadap independensi Kurator dalam melaksanakan kewenangan mengurus dan membereskan harta pailit.

\section{PEMBAHASAN}

Independensi Kurator dalam Melaksanakan Tugas Membereskan Harta Pailit Menjadi Penyebab Munculnya Gugatan dari Debitor Pailit

Gugatan dalam kehidupan sehari sering juga disebut tuntutan, dakwaan atau eis. Sementara itu sarjana lain menyebutkan bahwa tuntutan hak, yaitu tindakan yang bertujuan memperoleh perlindungan yang

3 Abdulkadir Muhammad. 2004. Hukum dan Penelitian Hukum. Bandung: Citra Aditya Bakti, hlm. 137. diberikan oleh pengadilan untuk mencegah "eigen rihcting". 4 Syarat mutlak untuk dapat mengajukan gugatan adalah adanya kepentingan langsung atau melekat dari si penggugat. Artinya tidak semua orang yang mempunyai kepentingan dapat mengajukan gugatan apabila kepentingan itu tidak langsung dan melekat pada dirinya. ${ }^{5}$

Terkait apakah independensi Kurator menjadi penyebab munculnya gugatan, UU No. 37/2004 menyebutkan, bahwa independen adalah kelangsungan keberadaan Kurator tidak tergantung pada debitor atau kreditor dan Kurator tidak memiliki kepentingan ekonomis yang sama dengan kepentingan ekonomis debitor atau kreditor. ${ }^{6}$

Ketua Asosiasi Kurator dan Pengurus Indonesia (AKPI) mengatakan, bahwa dalam hal Kurator tidak independen tentu akan membuat salah satu pihak merasa dirugikan, maka setiap orang yang merasa dirugikan mempunyai hak hukum untuk melakukan gugatan tersebut. Sepanjang Kurator dapat membuktikan bahwa tindakan Kurator dalam melakukan proses pemberesan sudah sesuai dengan aturan yang berlaku maka tidak masalah. $^{7}$

Perilaku yang melanggar kode etik Kurator antara lain mengenai tidak independennya kurator, serta tidak mematuhi standar profesi. Misalkan Kurator merupakan mantan kuasa hukum dari salah satu pihak, maka Kurator yang ditunjuk dianggap tidak independen. ${ }^{8}$

4 Darwan Prinst. 2002. Strategi Menyusun dan Menangani Gugatan Perdata. Bandung: Citra Adtya Bakti, hlm. 2.

5 Darwan Prinst, Op. Cit. hlm. 2

6 Lihat Pasal 15 ayat (3) UU No. 37/2004.

7 Ibid

8 Jamaslin Purba, Independensi dan Perlindungan Kurator, Wawancara, Jakarta, 4 September 2015. 
Apabila ada pelanggaran kode etik oleh Kurator anggota AKPI, biasanya langsung diproses secara kode etik Kurator. Tentunya Kurator yang diindikasikan bermasalah harus dilaporkan terlebih dahulu baik oleh sesama anggota Kurator maupun oleh pihak yang merasa dirugikan. ${ }^{9}$

Sudah menjadi hak semua warga negara yang merasa dirugikan dapat melakukan upaya hukum melalui gugatan maupun pelaporan kepada pihak berwenang ketika merasa dirugikan, jika hal ini dikaitkan dengan independensi sebagai salah satu penyebab munculnya gugatan oleh debitor maupun kreditor itu sangat wajar. ${ }^{10}$ Hakim pengawas selaku orang yang memiliki tugas melakukan pengawasan terhadap Kurator dalam mengurus dan membereskan harta pailit, tidak boleh intervensi terhadap permasalahan tersebut. Proses gugatan yang dilakukan oleh debitor maupun kreditor pailit ini tentu akan memberi berpengaruh terhadap proses pemberesan dan pengurusan harta pailit yang menimbulkan ketidakpastian penyelesaian pemberesan harta pailit itu sendiri terkait efesiensi waktu pemberesan yang semakin lama. ${ }^{11}$

Gugatan oleh kreditor ataupun debitor pailit atas tindakan yang dilakukan oleh Kurator dalam membereskan harta pailit, maka dapat saja independensi Kurator menjadi penyebab gugatan itu terjadi. ${ }^{12}$ Jika debitor atau kreditor menggugat dengan alasan dan dasar hukum yang jelas, tidak masalah, misalnya

9 Ibid

10 Bambang Setianto, Independensi dan Perlindungan Kurato, Wawancara, Pengadilan Niaga Semarang, 27 Agustus 2015.

11 Ibid

12 Anselmus B.P Sitanggang, Independensi dan Perlindungan Kurator , Wawancara, Kurator, Jakarta, 2 September 2015. gugatan agar harta yang sudah terlanjur dicatat dalam daftar budel pailit dikeluarkan dari budel pailit karena menurut mereka itu bukan harta debitor pailit. Dengan adanya gugatan tersebut malah akan membuat status harta menjadi jelas apakah memang budel atau bukan. Faktanya dari beberapa kasus gugatan terhadap Kurator, debitor pailit maupun kreditor yang bertujuan untuk menghambat proses pemberesan ini yang sulit, karena mau tidak mau kurator harus mengikuti dan akhirnya biaya kepailitan membengkak dan waktu yang dibutuhkan untuk membereskan menjadi lebih lama. ${ }^{13}$

Munculnya gugatan dikarenakan independensi dalam hal siapa yang menunjuk Kurator perlu diketahui bahwa Independensi Kurator bukan ditentukan dari siapa yang menunjuk, melainkan lebih kepada balancing atau keseimbangan antara kepentingan para kreditur dan kepentingan debitur dalam satu perkara kepailitan. Gugatan itu seringkali merupakan tindakan yang dipergunakan baik oleh debitur pailit atau kreditur dalam pemenuhan atau menuntut apa-apa yang dianggap haknya menurut UU No. 37/2004. ${ }^{14}$

Terhadap gugatan yang dilakukan oleh debitor maupun kreditor pada dasarnya tidak dapat hanya disebabkan oleh independensi terkait siapa yang melakukan permohonan penunjukan Kurator, hal ini dikarenakan Pengangkatan Kurator adalah sepenuhnya kewenangan Hakim Pengadilan (Hakim Pemutus).

Maksud dari Pasal 15 ayat (1) UU No. 37/ adalah itikad baik dari debitor atau kreditor sebagai pemohon pailit untuk menunjuk

13 Ibid

14 Yuda yustisia, Independensi dan Perlindungan Kurator, Wawancara, Surabaya, 8 September 2015. 
Kurator, mengenai pengangkatan Kurator, sebenarnya hal tersebut bukan kesalahan dari Hakim Majelis sebagai orang yang memiliki kewenangan memutuskan penunjukan Kurator yang menangani pemberesan dan pengurusan harta pailit, tetapi dapat saja hal itu dikarenakan Kurator yang ditunjuk oleh pemohon baik debitor maupun kreditor yang kemudian dimintakan pengangkatannya kepada Hakim Majelis merupakan Kurator yang itu-itu saja, sehingga seharusnya para pengacara yang mewakili pihak pemohon tidak menggunakan Kurator yang itu-itu saja tersebut. Agar penunjukan Kurator menjadi independen dan tidak ada benturan kepentingan dengan para pihak.

Independensi sebagai salah satu penyebab munculnya gugatan oleh debitor maupun kreditor dapat terjadi, tetapi perlu dilihat lagi apakah gugatan debitor atau kreditor memiliki alasan dan dasar hukum yang jelas. Dilihat dari tujuan dari gugatan yang dilakukan oleh debitor pailit mapun kreditor dalam beberapa kasus hanyalah upaya mengambil atau mengeluarkan aset dari budel pailit yang dikuasai oleh Kurator. Jika tujuan dari gugatan tersebut untuk memperjelas harta tersebut memang bukan bagian dari budel pailit tentu tidak menjadi permasalahan. Hanya saja ketika gugatan yang dilakukan dengan tujuan agar harta yang sudah menjadi budel pailit menjadi harta pribadi ini yang akan memberi pengaruh terhadap efesiensi proses pemberesan dan pengurusan harta pailit oleh Kurator dan juga dapat menimbulkan kerugian kepada para kreditornya, begitu juga sebaliknya jika yang yang melakukan gugatan adalah kreditor dengan tujuan sama.

Kedepannya diperlukan aturan yang mengatur mengenai sanksi terhadap tindakan debitor yang dapat merugikan kreditor atau sebaliknya yang dapat menghambat tugas Kurator dalam proses pemberesan dan pengurusan harta pailit setelah adanya putusan pailit, agar debitor pailit maupun kreditor tidak dapat dengan mudah mengajukan gugatan terhadap proses pemberesan dan pengurusan harta pailit yang dilakukan oleh Kurator apabila terbukti memiliki tujuan yang tidak baik.

\section{Bentuk dan Tolak Ukur Independensi Kurator Privat Menurut Undang-Undang Kepailitan dan Penundaan Kewajiban Pembayaran Utang}

Dalam Kamus Besar Bahasa Indonesia tidak ditemukan definisi dari pada independen tetapi memiliki padanan kata yakni mandiri. ${ }^{15}$ Kemandirian, bebas yang memiliki makna tidak memiliki ikatan pada pihak lain dalam melakukan segala bentuk aktifitasnya, bebas, otonomi, ketidak berpihakan, kemandirian, atau hal lain yang memiliki persamaan makna tidak memiliki ketergantungan pada organ atau lembaga lain dan dapat menjalankan tindakan sendiri termasuk dalam membuat suatu keputusan. ${ }^{16}$

Independensi Kurator selain dari ketentuan Pasal 15 ayat (3) UU No. 37/2004, hanya dapat dilihat dari keseimbangan antara kepentingan para kreditor dan kepentingan debitor dalam satu perkara kepailitan. Intinya menjembatani kepentingan para kreditor dengan kepentingan debitor. Harta debitor tidak menjadi rebutan para kreditor, dan hasil penjualan harta dapat di bagi secara tepat kepada para kreditor sesuai dengan aturan yang ada artinya tidak

15 Departemen Pendidikan Nasional. 2005. Kamus Besar Bahasa Indonesia, Edisi Ketiga. Jakarta: Balai Pustaka, hlm. 655.

16 http://digilib.unila.ac.id/8899/3/BAB\%20II .pdf, diakses pada tanggal 20 Mei 2015. 
ada keberpihakan Kurator terhadap salah satu pihak dalam melakukan pemberesan dan pengurusan harta pailit. ${ }^{17}$

Pada saat Kurator dimohonkan untuk menjadi Kurator dalam suatu perkara kepailitan, maka Kurator harus membuat surat pernyataan kesediaan untuk menjadi Kurator dalam perkara tersebut. Di dalam surat pernyataan tersebut dengan "menyatakan bahwa Kurator tidak memiliki konflik/benturan kepentingan terhadap pemohon atau termohon pailit" dan tidak sedang menangani lebih dari 3 (tiga) perkara kepailitan. ${ }^{18}$ Apabila Kurator merasa ada benturan kepentingan yang dapat menyebabkan Kurator tidak independen maka menurut Pasal 71 UU No. 37/2004 dan kode etik profesi, Kurator dapat minta agar diganti. ${ }^{19}$

Menurut Ketua AKPI, bahwa independensi yang dimaksud dalam Pasal 15 UU No. 37/2004 dan ketentuan dalam Kode etik profesi Kurator dan Pengurus Indonesia, bahwa Kurator tidak memiliki kepentingan dengan salah satu kreditor ataupun debitor, tidak memiliki hubungan keluarga dan tidak pernah menjadi kuasa hukum salah satu kreditor mapun debitor pailit. Artinya Kurator tidak memiliki kepentingan dengan pemberesan harta pailit yang ditanganinya serta tidak sedang menangani lebih dari 3 (tiga) perkara pemberesan harta pailit. Jadi, dapat dilihat dari situ saja independen atau tidak kurator. ${ }^{20}$

17 Yuda Yustisia, Independensi dan Perlindungan Kurator, Wawancara, Surabaya, 8 September 2015.

18 Bambang Setianto, Independensi dan Perlindungan Kurator, Wawancara, Pengadilan Niaga Semarang, 27 Agustus 2015.

19 Ibid

20 Jamaslin Purba, Independensi dan Perlindungan Kurator, Wawancara, Jakarta 4 September 2015.
Hanya saja sulit untuk AKPI sendiri untuk mengetahui apakah setiap anggotanya benarbenar menangani 3 (tiga) perkara kepailitan atau lebih, karena sifat orgnisasi yang pasif artinya ketika ada pelanggaran yang terjadi mengenai independensi tersebut haruslah orang yang merasa dirugikan yang melaporkan kepada organisasi AKPI. ${ }^{21}$

Tidak ada ketentuan mengenai tolak ukur/parameter independensi Kurator dalam melaksanakan tugasnya, tetapi memang didalam ketentuan UU No. 37/2004, menyebutkan bahwa independen yang dimaksud jika dikaitkan dengan pengertian secara luas, maka tentu yang dimaksud independen itu adalah tidak ada intervensi baik dari kreditor maupun debitor, merdeka dan mandiri. Dengan definisi tersebut, maka Kurator sudah dapat dikatan independen, dan selama melakukan pengawasan terhadap Kurator sejauh ini Kurator masih independen dalam melaksanakan tugasnya. ${ }^{22}$

Independesi Kurator saat ini sulit diidentifikasi oleh hakim pengawas, apalagi Kurator tersebut memiliki benturan/konflik kepentingan atau tidak dengan salah satu pihak debitor pailit maupun kreditor. Kurator harus memberikan surat keterangan kalau kurator tidak memiliki hubungan atau konflik kepentingan debitor pailit yang disampaikan bersamaan dengan surat pernyataan/keterangan yang disampaikan depan majelis hakim bahwa Kurator tersebut tidak menangani perkara kepailitan lebih dari 3 (tiga) perkara. Namun keabsahan atau kebenaran dari kedua surat keterangan tersebut sulit dibuktikan oleh hakim pengawas, karena tidak ada hakim yang dapat tahu kalau seandainya Kurator

\footnotetext{
21 Ibid

22 Op. Cit Bambang Setianto
} 
melakukan pemberesan harta pailit dikota lain. ${ }^{23}$

Menentukan parameter Independensi Kurator agak-agak sulit, kalau merujuk pada ketentuan Pasal 15 UU No. 37/2004, independen maksudnya adalah, Kurator dalam proses pengurusan dan pemberesan tidak boleh terikat dengan pihak lain yang dapat mengakibatkan pihak lain mengalami kerugian. $^{24}$

Menurut kode etik profesi Asosiasi Kurator dan Pengurus Indonesia (AKPI), Kurator AKPI harus memegang prinsip independensi dan benturan kepentingan. ${ }^{25}$ Apabila ada pelanggaran kode etik terkait independensi dan benturan kepentingan oleh Kurator anggota AKPI, biasanya langsung diproses secara kode etik Kurator. Kurator yang diindikasikan bermasalah harus dilaporkan terlebih dahulu oleh pihak yang merasa dirugikan. Apabila Kurator terbukti melakukan pelanggaran maka Asosiasi akan memberikan sanksi berupa teguran secara tertulis, peringatan keras dengan surat, pemberhentian sementara dari keanggotaan asosiasi pemberhentian sebagai anggota asosiasi. ${ }^{26}$ Ini dapat dikatakan sebuah kelemahan bagi kode etik karena sangat kecil kemungkinan sesama anggota dalam sebuah organisasi mau melaporkan rekan sesama anggota kepada AKPI apabila ada indikasi pelangaran tersebut

Ketentuan mengenai surat keterangan atau pernyataan Kurator tidak memiliki hubungan atau konflik kepentingan debitor

\section{Ibid}

24 Anselmus B.P Sitanggang, Independensi dan Perlindungan Kurator, Wawancara, Jakarta, 2 September 2015.

25 Ibid

26 Jamaslin Purba, Independensi dan Perlindungan Kurator, Wawancara, Jakarta, 4 September 2015. pailit yang disampaikan bersamaan dengan surat pernyataan/keterangan yang disampaikan didepan Majelis Hakim bahwa Kurator tersebut tidak menangani perkara kepailitan lebih dari 3 (tiga) perkara. Keabsahan atau kebenaran dari kedua surat keterangan tersebut sulit dibuktikan oleh hakim pengawas, karena tidak ada hakim yang dapat tahu kalau seandainya Kurator melakukan pemberesan harta pailit di kota lain.

Keterangan dalam Pasal 15 ayat (3) UU No. 37/2004 belum cukup spesifik, hal ini dapat dilihat dari pembatasan terhadap Kurator dalam menangani perkara pailit, yaitu tidak sedang menangani lebih dari 3 (tiga) perkara pailit, akan menjadi pertanyaan apakah aturan tersebut berlaku bagi Kurator yang menangani perkara secara tim, hal ini tidak dijelaskan UU No. 37/2004. Akibatnya dalam praktek dan banyak contoh kasus, Kurator secara tim dapat menangani perkara pailit dapat lebih dari 3 (tiga) perkara pailit. ketidakjelasan ini menjadi celah untuk dimanfaatkan oknum Kurator nakal.

AKPI sebagai salah satu organisasi tidak dapat mengetahui apakah setiap anggotanya benar-benar menangani 3 perkara kepailitan atau lebih mengingat sifat organisasi yang pasif, setiap ada pelanggaran yang dilakukan oleh anggotanya terkait dengan kode etik hanya akan diproses dengan adanya laporan kepada organisasi AKPI, sepanjang tidak ada laporan maka kurator dianggap independen, sehingga tidak ada jaminan yang pasti bahwa Kurator benar-benar melaksanakan ketentuan UU No. 37/2004, mengingat tidak ada pengawasan tentang hal itu baik dalam UU No. 37/2004 itu sendiri maupun dalam kode etik oganisasi dimana Kurator terdaftar sebagai anggota. 
Seharusnya adanya aturan mengenai tindakan pengawasan terhadap anggota dari asosiasi terhadap setiap anggotanya sebagai salah satu tindakan preventif terhadap terjadinya pelanggaran kode etik yang dilakukan oleh Kurator dan diperlukan kerjasama AKPI dengan Pengadilan Niaga mengenai pendataan Kurator yang sedang menangani perkara kepailitan di setiap Pengadilan Niaga secara berkala. Dengan adanya aturan tersebut tentunya akan terlihat apakah Kurator sedang menangani lebih dari 3 (tiga) perkara kepailitan baik secara individu maupun tim, sehingga apabila ada pelanggaran dapat langsung ditindaklanjuti tanpa harus menunggu adanya laporan dari pihak yang merasa dirugikan.

\section{Perlindungan Hukum Terhadap Kurator dalam Melaksanakan Kewenangan Mengurus dan Membereskan Harta Pailit}

Hukum pada dasarnya berfungsi untuk memberikan perlindungan kepada setiap kepentingan manusia. Hal itu disebabkan dalam kehidupan dan hubungan hukum, para pihak yang terkait mempunyai kepentingannya masing-masing. Kepentingan dimaksud adakalanya bersamaan, berbeda atau bahkan bertentangan. Dalam hal kepentingan tersebut bersamaan barangkali tidak akan menimbulkan masalah dalam kehidupan atau hubungan hukum tesebut. Demikian pula dalam hal kepentingannya berbeda, tetapi tidak dipertentangkan atau tidak dipersoalkan. Menjadi masalah dalam hal kepentingan tersebut bertentangan dan dimunculkan kepermukaan, sehinga menimbulkan suatu konflik kepentingan. ${ }^{27}$

27 Man S. Sastrawidjaja. 2006. Hukum Kepailitan dan Penundaan Kewajiban Pembayaran Utang. Bandung: Alumni, hlm. 71.
Konsep perlindungan hukum sendiri secara khusus telah tercermin dalam UUD 1945, dimana di dalam UUD 1945 mengamanatkan untuk memberikan perlindungan hukum tanpa terkecuali. Hukum dapat dimaknai sebagai perlindungan kepentingan manusia yang berbentuk norma dan kaidah. Kumpulan norma dan kaidah ini mengandung isi yang bersifat umum dan normatif umum karena berlaku bagi setiap orang. Setiap produk hukum yang dihasilkan oleh pemerintah ataupun badan legislatif senantiasa harus berpedoman pada UUD 1945 harus mampu memberikan perlindungan hukum kepada setiap insan yang menjadi bagian dari Negara Kesatuan Republik Indonesia.

Perlindungan hukum bagi Kurator berdasarkan UU No. 37/2004 yaitu, debitor tidak dapat menghalangi ataupun melakukan tindakan-tindakan penolakan terhadap kehadiran Kurator yang bertugas, dikarenakan kewenangan untuk melakukan pengurusan dan pemberesan harta pailit oleh Kurator untuk melaksanakan tugas dan kewenangannya telah diatur dalam UU No. 37/2004. Apabila ketentuan Pasal 24 dipatuhi oleh debitor pailit tentunya Kurator tidak akan kesulitan untuk pelaksanaan tugas dan kewenangannya ${ }^{28}$

Kurator bergerak untuk pelaksanaan tugasnya setelah ada putusan Pengadilan Niaga dan karenanya punya kewenangan yang diatur oleh UU No. 37/2004. Berdasarkan Kitab Undang Undang Hukum Pidana (KUHP), walaupun Kurator memasuki pekarangan orang lain (debitor) tanpa seijinnya dan/ atau melakukan perbuatan pidana, sepanjang berkaitan dengan tugasnya berdasarkan

28 Anselmus B.P Sitanggang, Independensi dan Perlindungan Kurator, Wawancara, Jakarta, 2 September 2015. 
undang-undang, maka perbuatan tersebut bukanlah tindak pidana. ${ }^{29}$

Misalkan dalam hal perdata, Kurator pernah ditunjuk untuk menjadi Kurator dari PT X. Menurut pemohon pailit, direktur PT X yang dimohonkan pailit ini dari awal sidang tidak mau hadir dalam persidangan, sehingga perkara tersebut diputus secara verstek dan majelis hakim mengabulkan permohonan pailit pemohon. ${ }^{30}$

Proses verifikasi ditetapkan tagihan para kreditor pada debitor pailit adalah kurang lebih Rp 14 Milyar. Oleh karena debitor pailit tidak mau kooperatif, selaku Kurator sangat kesulitan untuk menemukan dan mengamankan harta pailit. Akhirnya Kurator mohon izin pada kreditor dan hakim pengawas untuk mengajukan gugatan pada direktur debitor pailit. Setelah mendapat izin dari hakim pengawas Kurator mengajukan gugatan. Dalam gugatan intinya Kurator mohon agar direktur dari PT X (pailit) dinyatakan telah melakukan perbuatan melawan hukum dan akhirnya Pengadilan Niaga Jakarta Pusat mengabulkan gugatan tersebut.$^{31}$

Di Indonesia ada 3 (tiga) organisasi Kurator, ada Ikatan Kurator dan Pengurus Indonesia (IKPI), Asosiasi Kurator dan Pengurus Indonesia (AKPI) dan Himpunan Kurator dan Pengurus Indonesia (HKPI). Pada prinsipnya ada perlindungan hukum bagi setiap anggota Organisasi tersebut, tetapi masih menggunakan mekanisme melalui lembaga Dewan Kehormatan, jadi apabila ada yang merasa dirugikan dan ingin meminta bantuan hukum dapat melakukan permohonan melalui

\footnotetext{
29 Ibid

30 Ibid

31 Ibid
}

Dewan Kehormatan dan selama ini sarana tersebut jarang dipergunakan oleh Kurator. ${ }^{32}$

Kode etik AKPI Pasal 5 menyebutkan bahwa AKPI wajib untuk memberikan perlindungan dalam hal terjadi ketidakadilan terhadap anggota sehubungan dengan pekerjaannya sebagai Kurator, perlindungan itu diberikan dalam bentuk misalkan bagi setiap anggota yang mengalami masalah hukum diberikan upaya hukum berupa pendampingan bagi Kurator yang digugat maupun dilaporkan oleh debitor pailit maupun kreditor secara cuma-cuma. ${ }^{33}$

Mengenai perlindungan terhadap gugatan maupun pelaporan yang dilakukan oleh debitor maupun kreditor pailitnya terhadap Kurator, sepanjang dapat dibuktikan bahwa kurator tidak melakukan penyimpangan, maka tentunya mereka akan bebas dari segala tuntutan maupun ganti rugi terhadap kerugian yang ditimbulkan, Kurator akan terlindungi secara otomatis dengan syarat kurator tersebut melakukan tugasnya sesuai prosedur yang diatur oleh UU No. 37/2004 dalam melaksankan pemberesan maupun pengurusan harta pailit. ${ }^{34}$ tetapi dalam hal lain perlu satu bentuk aturan yang termuat didalam ketentuan UU No. 37/2004 yang mendetail mengenai hal-hal apa saja yang tidak dapat dilakukan oleh Kurator, misalkan dalam ketentuan Pasal 72 yang menyebutkan bahwa Kurator harus bertanggungjawab terhadap kelalaian dalam melaksanakan tugasnya, aturan tersebut tidak memberikan pejelasan kelalaian yang seperti apa yang dapat dikenakan terhadap Kurator,

32 Jamaslin Purba, Independensi dan Perlindungan Kurator, Wawancara, Jakarta, 4 September 2015.

33 Ibid

34 Bambang Setianto, Independensi dan Perlindungan Kurator, Wawancara, Pengadilan Niaga Semarang, 27 Agustus 2015. 
sehingga Kurator dapat dikatakan lalai dalam melaksanakan tugasnya. ${ }^{35}$

Tidak secara khusus UU No. 37/2004 mengatur mengenai perlindungan hukum terhadap Kurator. Bukan berarti Kurator tidak mempunyai perlindungan hukum dalam melaksanakan kewenangannya, apabila dalam hal Kurator dapat dengan mudah melaksanakan tugasnya untuk kepentingan para kreditor dan debitor pailit sesuai ketentuan UU No. 37/2004. Artinya kebebasan Kurator dalam melaksanakan tugasnya membereskan harta pailit sesuai aturan, maka Kurator dilindungi kewenangannya oleh undang-undang, termasuk sikap independensi Kurator dalam melaksanakan tugasnya.

Jaminan perlindungan hukum juga sudah diatur dalam Pasal 28D ayat (1) UUD 1945 yang menyebutkan "Setiap orang berhak atas pengakuan, jaminan, perlindungan, dan kepastian hukum yang adil serta perlakuan yang sama di hadapan hukum".

Terkait gugatan yang dilakuan debitor pailit maupun kreditor terhadap kewenangan Kurator dalam melaksanakan pemberesan dan pengurusan harta pailit, Pasal 28D ayat (1) UUD 1945, memberikan pijakan dasar dan perintah konstitusi untuk menjamin setiap warga Negara, untuk mendapatkan akses terhadap warga negara untuk mendapatkan pengakuan, jaminan, perlindungan, dan kepastian hukum yang adil serta perlakuan yang sama di hadapan hukum. Apabila Kurator mengalami permasalahan hukum dalam menjalankan tugasnya maka Kontitusi negara, yaitu UUD 1945 sudah memberikan jaminan perlindungan tersebut dan AKPI sebagai salah satu organisasi juga telah mempersiapkan perlindungan hukum terhadap anggotanya

35 Ibid yang mendapatkan permasalahan hukum didalam menjalankan profesi sebagai Kurator ataupun pengurus. ${ }^{36}$ yaitu dengan adanya Bidang Advokasi (perlindungan hukum) di dalam susunan bidang kepengurusan AKPI. Bidang Advokasi ini khusus memberikan bantuan hukum secara cuma-cuma terhadap anggota AKPI yang terjerat permasalahan hukum didalam menjalankan tugasnya sebagai Kurator maupun Pengurus. Meski telah diatur, para Kurator yang digugat oleh debitor pailit maupun kreditor jarang meminta bantuan kepada Asosiasi, hal ini dikarenakan Kurator Kurator tesebut merasa berlum perlu meminta bantuan AKPI.

UU No. 37/2004 tidak mengatur bahwa Kurator dalam melaksanakan tugas dan kewenangannya tidak dapat digugat atau dilaporkan oleh pihak yang merasa dirugikan. Karena pada dasarnya sudah menjadi hak setiap orang atau badan hukum yang merasa dirugikan dapat melakukan tindakan hukum berupa gugatan maupun pelaporan atas kerugian yang diderita oleh orang yang memiliki kepentingan sebagai akibat dari perbuatan Kurator. Hanya saja akibat gugatan tehadap Kurator, dapat menimbulkan waktu pemberesan yang semakin lama dikarenakan aset tidak dapat dilelang atau dijual dalam jangka waktu cepat sehingga biaya yang dikeluarkan untuk pengamanan aset selama perselisihan terjadi menjadi tanggungan Kurator secara pribadi. Selain itu juga dapat menimbulkan ketidak pastian mengenai pembayaran piutang bagi para kreditor setelah adanya putusan pailit terkait aset yang masih diperebutkan Kurator dan debitor pailit.

36 Pasal 5 ayat (2) Kode Etik Asosiasi Kurator dan Pengurus Indonesia 
UU No. 37/2004 memberikan kewenangan Kurator dalam melaksanakan tugasnya selama pemberesan dan pengurusan harta pailit. Ketentuan tersebut merupakan bentuk perlindungan yang diberikan kepada Kurator dalam melaksanakan tugasnya, meskipun kewenangan dalam melaksanakan tugas tesebut, di lapangan tidak dapat berjalan sesuai harapan dikarenakan banyaknya kendala yang harus dihadapi oleh Kurator selama pemberesan harta pailit. Mulai dari sulitnya mengeksekusi harta pailit yang dikuasai pihak lain kemudian debitor pailit atau kreditor nakal yang melakukan gugatan dengan berbagai alasan dengan tujuan mengeluarkan sebagian harta dari budel pailit ini yang sampai sekarang masih menjadi masalah bagi Kurator dalam pengurusan dan pemberesan harta pailit.

Adanya jaminan perlindungan hukum secara umum telah diatur didalam UUD 1945 Pasal 28D ayat (1), tetapi diperlukan salah satu bentuk aturan yang termuat di dalam ketentuan UU No. 37/2004 yang mendetail, misalkan dalam ketentuan Pasal 72 dalam hal apa saja kurator dapat dikatakan lalai dalam melaksanakan tugasnya, agar kewenangan Kurator dalam melaksanakan tugasnya benar-benar dapat terlidungi, sehingga proses pemberesan dan pengurusan harta pailit dapat berjalan sesuai aturan yang berlaku, tanpa hambatan untuk kepentingan debitor pailit dan para kreditor.

\section{SIMPULAN}

a. Permasalahan independensi terkait siapa yang melakukan permohonan penunjukan Kurator bukanlah penyebab utama munculnya gugatan oleh debitor maupun kreditor, meskipun itu dapat terjadi. Gugatan terhadap Kurator yang dilakukan oleh debitor maupun kreditor pada dasarnya yang dialami Kurator selama ini hanya bertujuan untuk menghambat proses pemberesan harta pailit, akibatnya waktu untuk pemberesan menjadi lebih lama dan biaya pengamanan aset membengkak. Ada juga gugatan yang diajukan dalam rangka pemenuhan hak-haknya yang tidak dipenuhi oleh Kurator, sehingga perkara gugatan debitor pailit mapun kreditor memang harus dilihat kasusnya.

b. Tidak ada ketentuan mengenai tolok ukur/ parameter independensi Kurator dalam melaksanakan tugasnya semua hanya dilihat dari ketentuan dan Penjelasan Pasal 15 ayat (3) UU No.37/2004, apabila terpenuhi kalaupun terjadi pelanggaran sepanjang hal itu tidak ada yang mengetahui tentu dianggap Kurator telah independen dalam melaksanakan tugasnya. Terdapat beberapa masalah mengenai independensi Kurator dalam melaksanakan tugasnya mengenai:

1) Keabsahan surat pernyataan Kurator tidak memiliki hubungan atau konflik kepentingan debitor pailit ataupun kreditor sulit dibuktikan oleh hakim pengawas.

2) Tidak adanya aturan mengenai pengawasan tehadap anggota Kurator oleh AKPI sebagai salah satu organisasi, sehingga asosiasi tidak dapat mengetahui apakah setiap anggotanya benar-benar sedang menangani 3 (tiga) perkara kepailitan atau lebih.

3) Pembatasan terhadap Kurator dalam menangani perkara pailit, yaitu tidak sedang menangani lebih dari 3 (tiga) perkara pailit. apakah aturan tersebut berlaku bagi Kurator yang menangani perkara secara tim. 
c. Secara impilist UU No. 37/2004 tidak mengatur mengenai perlindungan hukum terhadap Kurator, tetapi kebebasan dalam setiap tindakan Kurator untuk melakukan pengurusan dan pemberesan harta pailit, misalkan Kurator tidak perlu meminta persetujuan debitor pailit dalam melakukan penjualan aset maupun pengelolaan aset selama dalam penguasaan Kurator adalah salah satu bentuk perlindungan hukum yang diberikan oleh UU No. 37/2004 terhadap kewenangan Kurator dalam melaksanakan tugasnya. Aturan perlindungan hukum terhadap Kurator juga telah termuat didalam:

1) Pasal 28D ayat (1) UUD 1945;

2) Pasal 5 ayat (2) Kode Etik Asosiasi Kurator dan Pengurus Indonesia wajib memberikan perlindungan hukum secara cuma-cuma terhadap anggotanya.

\section{DAFTAR PUSTAKA}

Departemen Pendidikan Nasional. 2005. Kamus Besar Bahasa Indonesia, edisi ketiga. Jakarta: Balai Pustaka.

Hartini, Rahayu. 2008. Hukum Kepailitan. Malang: UMM Press.

Muhammad, Abdulkadir. 2004. Hukum dan Penelitian Hukum. Bandung: Citra Aditya Bakti.

Prinst Darwan. 2002. Strategi Menyusun dan Menangani Gugatan Perdata. Bandung: Citra Adtya Bakti.
Sastrawidjaja Man S. 2006. Hukum Kepailitan dan Penundaan Kewajiban Pembayaran Utang. Bandung: Alumni.

\section{Peraturan Perundang-undangan}

Undang Undang Dasar Negara Republik Indonesia Tahun 1945.

Kitab Undang Undang Hukum Perdata (Staatsblad Tahun 1847 Nomor 23)

Kitab Undang Undang Hukum Pidana (Staatsblad Tahun 1915 Nomor 732)

Undang Undang Nomor 37 Tahun 2004 tentang Kepailitan dan Kewajiban Penundaan Pembayaran Utang (Lembaran Negara Republik Indonesia Tahun 2004 Nomor 131, Tambahan Lembaran Negara Republik Indonesia Nomor 4433).

Undang Undang Nomor 40 Tahun 2007 tentang Perseroan Terbatas (Lembaran Negara Republik Indonesia Tahun 2007 Nomor 106, Tambahan Lembaran Negara Republik Indonesia Nomor 4756).

Peraturan Menteri Hukum dan Hak Azasi Manusia Nomor 18 Tahun 2013 tentang Syarat dan Tata Cara Pendaftaran Kurator.

\section{Kode Etik dan Standar Profesi}

Kode Etik Profesi Asosiasi Kurator dan Pengurus Indonesia.

Standar Profesi Kurator dan Pengurus.

\section{Internet}

http://bisniskeuangan.kompas.com/Dirut. Batavia.Air.Gugat.Balik.Tim.Kurator, diakses pada tanggal 18 Juli 2015. http://digilib.unila.ac.id/8899/3/BAB\%20II. pdf., diakses pada tanggall 20 Mei 2015. 